\title{
Pastorale interaksie met vroue - gesien vanuit die beelde wat vir God gebruik word
}

\author{
Yolanda Dreyer \\ Tydelik-deeltydse dosent: Department Praktiese Teologie (Afd A) \\ Universiteit van Pretoria
}

\begin{abstract}
Pastoral care and counseling with women: God-images and the identity of women

The focus of this article is on women in the pastoral care situation. Rather than the revolutionary approach of liberation theology, a choice is made here for a process of conscientisation. Consciousness should be raised concerning the harm that has come to women on account of the dominant male perspective. A correlation is drawn between a conception of Scripture, God-images (King/Lord, Father, Friend, Mother) and the identity of women. The article concludes with an orientation of church and society within a postmodern paradigm toward an authentic life for women before God.
\end{abstract}

\section{INLEIDING}

Do no more harm, was die woorde waarmee dr. Christie Cozad Neuger in 1989 die eerste lesing van die herfssemesterkursus Pastoral Care and Counseling with Women aan die Princeton Theological Seminary, in die VSA begin het. Hierdie woorde is gerig aan praktiserende en voornemende pastors. Die vooronderstelling wat duidelik klink uit die woorde, is dat vroue, wanneer hulle na 'n pastor toe kom, reeds blootgestel was aan skade. Die appel is dat pastors in hulle hulpverlening nie verder sal bydra tot hierdie skade nie. Dit is 'n verontrustende idee om te oorweeg dat pastors moontlik skade of verdere skade kan berokken aan mense wat na hulle toe kom vir hulp. Die vrae wat hierdie appel aan pastors oproep, is: watter moontlike of verdere skade kan pastors aan vroue doen? En: hoe kan sulke skade voorkom word sodat die pastorale proses vir vroue positief, konstruktief en waarlik hulpgewend kan verloop? Die ondersoek van hierdie vrae, is die fokus van dié studie.

* Hiendie artikel is 'n verwerking van die resultate van 'n deel uit veral boofstuk 7 van die DDproefskcrif 'Pastorale interaksie met vroue: 'n Prakties-Teologiese begronding', ingedien en anvasa as deel van die vereistes vir die DD-graad (1998), Departement Praktiese Teologie, Fakulteit Teologie (Afd A), Universiteit van Pretoria, onder leiding van prof dr T F J Dreyer (promotor) en prof dr A G van Aarde (mede-promotor). 
Pastorale interaksie met vroue vind plaas binne kerklike en sosiale strukture wat hiërargies vorm aanneem. Wanneer in hierdie hiërargiese strukture die manlike perspektief corheers, bewustelik of onbewustelik mag oor ander uitgeoefen word, implisiete norme in die ekonomie, politiek, familie en kerk verhinder dat outentieke menswees vir vroue binne die strukture realiseer, is daar konflikpotensiaal.

Pastorale werk met vroue word hoofsaaklik gedoen deur mans. Selfs vroue wat pastorale werk doen, is geinstitusionaliseer binne 'n manlik-gedomineerde wêreld. Die pastoraat vind dus hoofsaaklik plaas vanuit 'n manlik-gedomineerde leefwêreld en verwysingsraamwerk. Die gevolg hiervan is dat vroue se ervaring, asook die waarde wat vroue toeken aan hulle eie ervaring, nie die fokus van die pastorale interaksie met vroue is nie. Binne die pastorale interaksie kan verskillende opsies orweeg word om hierdie skade teen te werk. Die pastoraat kan byvoorbeeld probeer om vanuit 'n feministiese bevrydingsteologiese perspektief vroue te bevry uit manlike hiërargie. Bevrydingsteologieē werk met 'n revolusionêre motief. Hierdie studie stel eerder 'n pastorale interaksie voor wat gerig is op 'n bewusmakingsproses van die skade wat berokken word en alles wat daarmee saamgaan. "Die bedoeling is dat pastors in staat sal wees om werklik vroue se volle mens-wees voor God te respekteer.

Vanuit hierdie grondhouding van respek sal die pastor en die vrouepastorant saamwerk tot genesing en herstel van die skade so ver moontlik. Verder sal die pastor en vroue saamwerk om vroue se weerbaratheid en innertike krag op te bou sodat die verdere onvermydelike lonflik en skede wat vir hulle voorle, hulle nie sal verhinder om outentiek voor God te ken lewe nio. In 'n artikel, getitel 'Hét postmoderne nog cens uitgelegd', verwoord Wim de Pater (1996:201) dit in post-modeme taal soos volg:

Het postmodernisme houdt de warschuwing in dat het christendom niet mag verworden tot cen gesloten, hegewonistisch verhaal dat de 'gebeurtenis' van het er-ann-komen van nieuwen zinnes uitschakelt omdat alles er al viutligt. Wij worden met aadere woorden uitgenodigd het christendom te beloven als cen open verhal dat gangbare verhalen bevrijdend dootbreakt. Dat was het christendom van corsprong en intentie, al maakte men er later soms wel wat anders van ... Theologisch betekent het openhouden van verbalen dat theologen hun denken weten te recontextualiseren ....

Hierdie bydrae het $s 0$ 'n 'rekontekstualisering' in die oog. In my doktorale proefskrif (Dreyer 1998:60-62, 246-289) het ek aangetoon dat daar 'n noue korrelasie tussen 
Skrifbeskouing, Godsbeelde en die identiteit van vroue bestaan. ' $n$ Mens se Godsbeeld is bepalend vir jou verhouding tot God. Dit is ' $n$ kernaspek van die geloofslewe omdat dit verskeie ander fasette van geloofsuitlewing bepaal. Die Godsbeeld het nie net 'n uitwerking op roe mense God sien en ervaar nie, maar ook op hoe hulle hulleself binne hulle verhouding tot God beleef, asook op hulle identiteit. Verder het die Godsbeeld van mense 'n effek op hoe hulle hulle naaste ervaar. Dit loop direk daarop uit hoe mense hulle naaste behandel en teenoor ander optree (vgl Mollenkott 1992:94; Washington 1997:344-363). As God byvoorbeeld gesien word as 'n oordelende regter, beleef die mens wat in verhouding tot God leef, hom- of haarself permanent in die beskuldigdebank. Dit word ' $n$ vreesbevange verhouding met ' $n$ konstant negatiewe toon. Die persoon se identiteit word dié van ontoereikende, slegte, skuldige mens. Dit is 'n negatiewe identiteit. Iemand wat vanui $i$ 'n negatiewe identiteit funksioneer, kan onmoontlik ander mense positief sien of behandel. As 'n mens in relasie lewe met 'n oordelende God wat reëls en wette vaslê, is dit net 'n klein treetjie verder tot by reëls en wette vaslè vir ander, oordeel oor hulle uitspreek en straf uitdeel.

Die teenoorgestelde is ook waar. Wie God sien as 'n genadige en liefdevolle God, sal haar- of homself beleef as ' $n$ begenadigde persoon. Dit is 'n positiewe identiteit wat lei tot 'n positiewe belewing van verligting en dankbaarheid. Vanuit so 'n positiewe ervaring van God en die eie identiteit is mense in staat om positief op te tree teenoor ander en met die naaste op 'n positiewe manier om te gaan. Vanuit die eie helewing van genade en liefde, wil die gelowige só leef en optree dat die ander ook iets van God se genade en liefde sal ervaar. God werk tog nie anders as deur mense.nie. Dieselfde dinamiek geld vir die korporatiewe identiteit van 'n geloofsgemeenskap.

(T)he way in which a faith community shapes language about God implicitly represents what it takes to be the highest good, the profoundest truth, the most appealing beauty. Such speaking, in turn, powerfully molds the corporate identity of the community and directs its praxis. A religion, for example, that would speak about a warlike god and extol the way he smashes his enemies to bits would promote aggressive group behavior ... On the other hand, speech about a beneficient and loving God who forgives offenses would turn the faith community toward care for the neighbor and mutual forgiveness.

(Johnson 1994:4) 
Die dominante Godsbeelde van die geloofsgemeenskap het 'n uitwerking op die vorming van 'n positiewe of negatiewe identiteit. Dit het weer 'n effek op die gemeenskap se houding en optrede teenoor (A)nder. Johann Beukes (1996:236) beskryf Foucault se bydrae in hierdie verband soos volg:

Vir Foucault tree die rede se ware aard na vore daar waar dit slaag om nie uit te sluit nie, maar die Ander - die histories gekleineerde - segmente van die werklikheid te herken, te erken en in te sluit. Ware redelikheid sou vir die postmoderne filosofie dus 'n redelikheid wees wat bereid is om met die Ander in die reine te kom: nie daar waar redelikheid die grense sluit en dele van die werklikheid verdring en uitban nie, maar daar waar dit die grense postmodern oopbuig en Ander werklikhede inlaat, en aan dit wat in die moderne bewussynsfilosofiese paradigma formeel nietig verklaar is, die nodige erkenning te verleen.

Die opskryf van historiese prosesse, die bewuswording van die geskiedenis, is vir Foucault om hierdie Ander tot spreke te bring (Beukes 1996:242). Vanuit 'n positiewe identiteit sal 'n geloofsgemeenskap nie net aan die eie lede en na buite toe God se liefde en genade verkondig nie, maar dit ook in die geloofsgemeenskap se houding en optrede teenoor mense modelleer wat God se genade beteken, naamlik heil, wat heling, herstel, heelheid genesing en dus die moontlikheid tot outentieke lewe voor God insluit.

\section{GODSBEELD EN IDENTITEIT}

Die dinamiek dat iemand se Godsbeeld die persoon se identiteit beinvloed en dat dit weer deurwerk na optredes teenoor ander, geld ook vir gelowige vroue. Hoewel die moderne teologie nou wel ronduit sê dat vroue ten volle beeld van God is, word die konsekwensies daarvan steeds nie voluit in die praktyk in geloofsgemeenskappe uitgeleef en vertoon nie. Die vrou se plek in die kerk is nog lank nie dié van volle vennootskap nie. Die effek wat dit op vroue het, is dat hulle steeds dikwels 'n stryd het om vertroue te hê in hulle eie beeld-van-God kwaliteit en dit te assimileer in hulle identiteit as volwaardige mense voor God en in die wêreld. Die effek van hierdie negatiewe erfenis op vroue se ervaring, is onder andere dat 'one of the female sins we are guilty of is that we do not really believe that we are God's image; we are only a kind of "afterthought" on the part of the creator' (Von Wartenberg-Potter 1987:99-100).

Wat kerk en teologie betref, word ook vroue as 'beelddraer' van God gesien. Maar wat van die omgekeerde? Wanneer mense praat oor God, kan dit nie anders as 
om te wees in terme en beelde wat uit mense se ervaringswêreld kom nie. As vroue nou wel as beeld van God aanvaar word, is dit dan ook aanvaarbaar om oor God te praat in terme en beelde wat kom uit vroue se leef- en ervaringswereld? Wat Godsbeelde betref, is dit in die praktyk nie algemeen of selfs aanvaarbaar dat daar ook in beelde en taal wat te doen het met vrou oor God gepraat word nie. Oor God word gepraat hoofsaaklik in manlike beelde en metafore en uitsluitlik in manlike grammatikale terme.

'n Logiese vraag wat hieruit sou vloei, is waarom dit so gedoen word? Word God dan beskou as manlik? Wat die kerk se leer oor God betref, is dit vanselfsprekend en duidelik dat God nie 'n geslagtelike wese is nie. God is dus nie manlik of vroulik of manlik én vroulik nie. Die leer van die kerk is egter nie dag vir dag onder mense se aandag nie. Die manlike taal, terme en beelde in alle spreke oor God, individueel en liturgies, is egter wel voortdurend vars in mense se ervaring. Hiervan sê die teoloog Marga Bührig (1993:60): 'All this speaks louder than the assurance, continually heard and quite honestly intended, and verifiable in many other ways, that God is obviously not exclusively one sex or the other. Men who are not aware of themselves and of their own position as God-given, are not wounded by this, and can easily dismiss women's criticism as laughable and trivial'.

Is hierdie realiteit van 'n oorweldigende assosiasie van God met alles wat manlik is, soos blyk uit die taalgebruik en alledaagse praktyk, indien dan nie in die leer van die kerk nie, skadelik vir vroue? Indien nie, is daar geen rede om enigiets te verander nie. Die kerk kan voortgan soos altyd met die wete dat dit vir alle lede van die geloofsgemeenskap moontlik is om binne die gemeenskap outentiek voor God te kan lewe. In die teologiese nadenke gaan dit om nadenke en spreke oor God. Of daar hoegenaamd oor God gepraat kan word, en indien wel hoe (en hoe nie), is 'n vraag wat teoloè en filosowe reeds eeve lank besig hou. Martin Buber (1953:16-18) worstel op 'n treffende wyse met die moontlikheid van spreke oor God:

What word of human speech is so misused, so defiled, so desecrated as this [the word 'God']! All the innocent blood that has been shed for it has robbed it of its radiance. All the injustice that it has been used to cover has effaced its features....

Yes, it is the most heavy-laden of all human words. None has become so soiled, so mutilated. Just for this reason I may not abandon it. Generations of men have laid their burden of their anxious lives upon this word and weighed it to the ground; it lies in dust and bears their whole burden ... But when all madness and delusion fall to dust, when they 
stand over against Him in the loneliest darkness and no longer say ' $\mathrm{He}$, He' but rather sigh 'Thou', shout 'Thou', all of them the one word, and when they than add 'God', is it not the real God whom they all implore, the One Living God, the God of the children of Man? ... We cannot cleanse the word 'God' and we cannot make it whole; but, defiled and mutilated as it is, we can raise it from the ground and set it over an hour of great care.

Hiermee plaas Buber homself teenoor die era wat hy as 'n 'Godsverduistering' beskryf. God is gerelegeer na daarbo of hierbenede, na immanent of transendent. God is beskryf as almagtige, opperheerser, misterie, manlik, die gans-Andere, as die eintlike rede, as deus ex machina totdat Nietzsche eindelik uitroep: 'God is dood ... ons het God doodgemaak'. Die mens het nie daarin geslaag om God vas te vang in mensgemaakte konsepte nie. Dietrich Bonhoeffer (1967:360) se laaste woorde was: Vir die wêreld om voort te gaan, het ons God nie langer as 'n morele, politieke, wetenskaplike, filosofiese of godsdienstige werkhipotese nodig nie. Al die ontologiese uitsprake oor God het die mens nêrens uitgebring nie. Nadat die wêreld deur die Godsverduistering gegaan het, word daar nie meer gevra hoe God is nie. Maar die mens kan steeds nie ophou vra waar God ontmoet kan word en wat God vir die mens se lewe beteken nie.

Wanneer daar ter wille van vroue se geestesgesondheid, volle positiewe identiteit as persone en gelowiges gevra word na die verbeelding van God in terme van vrouemetafore, gaan dit nie om ontologiese eienskappe van God nie. Dit gaan oor die wyses waarop vroue God ervaar en die effek wat dit op hulle lewens het (vgl Von Wartenberg-Potter: 1987:93).

\section{TAALAANDELING}

Mense het nog altyd hulle ervaring van God in menslike beelde en menslike taal beskryf. Dit kan nie anders nie. Menslike woorde en beelde is al wat beskikbaar is. 'it Feit van die Christelike erfenis is dat net die mans, vanweë die institusionalisering binne die patriargale samelewing, die reg gehad het om te praat en oor die mag van kennis en die pen beskik het. Die gevolg daarvan is dat manlike woorde in die beelde en taal van mense en in die spreke oor God die botoon voer. Hierdie swaar manlikgeoriënteerde erfenis in die taal en beelde van mense se spreke oor God, is 'n gegewe, 'n feit van die geskiedenis. Dit is vasgelê in alles wat ons het: in die Bybel, die teologie, die liturgie, die gesangboeke. Daar is deesdae 'n veel groter bewussyn van die patriargale agtergrond van die Bybel en die eensydig manlike perspektief van 'die too- 
logie'. Dikwels bly dit slegs 'n akademiese bespreking en daar word versuim om na die praktiese effek van dit alles in die liturgie en in die pastorale praktyk te gaan kyk.

'n Interessante studie van die liturgiese praktyk en geslagtelike taalgebruik is gedoen deur 'n Britse predikant en teoloog uit die Reformatoriese tradisie, Brian Wren. Hy het ' $n$ analise gemaak van hoe manlike en vroulike beelde en taal gebruik word in die eerste 328 liedere in die 1983 gesangeboek Hymns and Psalms: A Methodist and ecumenical hymnbook. Die afdeling waarbinne hierdie spesifieke liedere voorkom, gaan oor 'die Goddelike natuur'. Wren (1989:117-118) het bevind dat manlike of androsentriese beelde $76,5 \%$ gebruik is, neutrale beelde $23,5 \%$ en vroulike beelde $0 \%$. In die nuwe Afrikaanse gesangeboek word gelowiges (dus ook vroue) in Gesang 258 opgeroep om hulle 'manlik, sterk en moedig' te gedra. In die ou gesangeboek was dit 'manlik en kloekmoedig'. Diegene wat die nuwe gesangeboek saamgestel het, het klaarblyklik bevind dat 'kloekmoedig' nie meer tot die modeme kerkganger sou spreek nie en het dit verander. Die oproep dat vrouegelowiges hulle 'manlik' moet gedra, was egter nie in 1978 'n probleem nie en is net so gelaat (kyk Die berymde psalms saam met die evangeliese gesange 1978:Ges 258).

In sy kommentaar oor die bevindings van sy studie, merk Wren op: 'If male and female humans really believed to be created as an equal partnership in the divine image, one would expect to find both feminine and masculine pronouns ... The fact that the genderless Trinity is prayed to and depicted in exclusively male images and pronouns must give humans a hooded one-eyed vision of God' (Wren 1989:117-118). $\mathrm{Na}$ die herkenning en erkenning van die patriargale erfenis en die 'hooded one-eyed vision of God' wat dit selfs tot in die hedendaagse kerklike praktyk tot gevolg het, is dit 'n volgende vraag wat hieraan gedoen behoort te word. Daar is diegene wat uitgaan van die standpunt dat ons die verlede, die tradisie (en veral die Bybel) nie kan verander nie. Dit moet so anvaar word (vgl Martin 1994:221-264). Dit word egter 'n probleem wanneer die erfenis van die geskiedenis en die tradisie 'n bepaalde skadelike effek op sekere mense skyn te hê.

'n Erfenis wat die man en alles wat manlik is, voorhou as die norm vir menswees, beteken vir mense wat nie aan daardie norm voldoen nie, dat hulle waarde en moontlikhede minder is. Beelde en metafore wat gebruik word in die spreke oor God, lewer 'n beduidende bydrae tot die boodskap wat vroue op verskeie maniere van die kerk en die samelewing ontvang. '... (T)he exclusively male images of God are keeping us [women] away from many possible experiences of God, and lock God away in an ontological male shrine from which the men derive their identity and supremacy' (Von Wartenberg-Potter 1987:96). Ek is met hierdie studie geinteresseerd in die effek wat dit alles het op vroue se geestesgesondheid, vroue se volwaardige identiteit as persone 
en as gelowiges, asook op vroue se moontlikheid tot outentieke lewe voor God. Hierdie sake vorm myns insiens die kern van die pastoraat met vroue.

Taal is nie 'n onskuldige, neutrale saak as dit kom by magsbelange, magsuitoefening en geslagtelikheid nie. Taalkritiek is vanuit ' $n$ vroueperspektief besonder belangrik, 'weil die Sprache einerseits unsere Wirklichkeit abbildet, sie andererseits aber auch beeinflußt und bestimmt. So kann am Sprachgebrauch die tatsächliche Frauenfeindlichkeit oder Frauenfreundlichkeit einer Gesellschaft abgelesen werden' (Scherzberg 1995:53). Wat geld vir taal in die algemeen, geld ook vir godsdienstige taal: 'Language not only represents or reflects experience but also shapes it. What is true for all language is also true for religious language' (Van Wijk-Bos 1995:5).

Hoewel vroue die groot meerderheid kerklidmate uitmaak, is dit oorweldigend mansstemme wat in kerke gehoor word. Dit is byna uitsluitlik mans wat deur middel van manlike beelde, name en metafore vir God en met manlike grammatika wat verwys na God, praat vanuit manlike verwysingsraamwerke, manlike ervaring van God en die werklikheid en 'n manlike perspektief. 'n Eensydig manlike Godsbeeld weerspreek die Christelike leer oor God en die Christelike mensbeeld, en kan tot gevolg hê dat mense se spiritualiteit ingeperk en skeefgetrek word. As die teologie dit as vanselfsprekend beskou dat God nie manlik is nie, dan mag dit sekerlik ook nie op die vlak van beelde, metafore en grammatika gesuggereer word dat God manlik is nie.

As vroue, net soos mans, geskape is na die beeld van God, moet dit ook duidelik word uit die beelde wat daar vir God gebruik word. Eensydigheid van enige aard verhinder mans en vroue om 'n outentieke spiritualiteit te ontwikkel (kyk Scherzberg 1995:79). Distorsies is te bespeur in sowel die werklikheid van die geloofsgemeenskap wat nie oorweldigend manlik is nie, as wat die Godbeeld betref. Oor die effek van sulke distorsies spreek die teoloog uit die evangelical tradisie, Virginia Mollenkott (1992:83-84) haar baie sterk uit:

... I hope readers will think about what happens when people with a distorted sense of masculinity are the ones who create God in the same distorted image ... And then Christians ... have legitimated those gender distortions by settling exclusively into certain biblical metaphors for God until those metaphors have developed the force of an idol. We have spoken of God as our Father, our King, and our Master so exclusively that we have forgotten the many other biblical metaphors that depict God in ways that would undercut male primacy and femaly secondariness and teach us a partnership model of relating. 
Daar is 'n wisselwerking tussen godsdienstige simbole en relasies in die samelewing. Ten opsigte van man-vrou verhoudings en geslagtelikheid, het hierdie wisselwerking onder andere die volgende moontlike konsekwensies: 'Dem Vater und Herrscher im Himmel entsprechen nur zu oft die männlichen Herrscher auf Erden und die Ehemänner, die sich als Häupter ihrer Frauen verstehen' (Scherzberg 1995:79). Die 'heersermodel' het heelwat potensiaal vir magsmisbruik. Van die gevaarlikste distorsies in die samelewing wat hiermee verband hou, is die siening dat 'regte mans' vroue en kinders onder beheer moet hou, selfs al sou geweld nodig wees om dit te doen. In sy studie oor die verband tussen geweld en geslagtelikheid in die Ou Testament wys Harold Washington (1997:334; vgl ook Bach 1998:1-19) op die effek wat die tekste het tot in ons tyd. Hy wys onder andere op die legitimering van geweld in van die wette in Deuteronomium 20:1-20; 21:10-14.

Volgens Mollenkott (1992:88-89) hou die distorsies ten opsigte van geslagtelikheid direk verband met eksklusief manlike, asook mag en beheer georiënteerde taal oor God. Elisabeth Schüssler Fiorenza (1996:9) stel dit so: 'Patriarchal religion and theology perpetuate and legitimate rape, wife-battering, child-abuse, sexual exploitation of women, second-class citizenship, and many more injustices against women'.... Hierdie verwronge relasies wat aangehelp word deur taal, doen aan vroue skade. Mary Daly (1979:19) wys daarop dat die metafore wat vir God gebruik word, op diepgaande wyse bepaal hoe mense hulleself sien. Identiteitsvorming is dus hier ter sprake. Die eksklusiewe manlike verwysings na God, weerhou vroue van 'n ervaring wat mans algemeen die vryheid en die voorreg het om beleef. Volgens haar word mans 'vergoddelik' deur die noue verbondenheid tussen mans en God in die taal en in die strukture en rituele van die groot godsdienste. So 'n 'vergoddeliking' gebeur ten koste van sowel vroue as God (vgl ook Anne Car 1988:138-139).

Taal wat uitsluitlik manlik is, onderskryf 'n wêreld wat vroue uitsluit of as ondergeskik en marginaal sien. Dit ondermyn vroue se menswaardigheid as mense wat geskape is na die beeld van God (kyk Van Wijk-Bos 1995:5-6; Johnson 1994:44-45). Om in die beeld van God trekke te ontdek waarmee 'n mens jouself kan identifiseer, is noodsaaklik vir godsdienstige sosialisering. In dié opsig is vroue in die kerk eensydig benadeel. Die skade wat vroue ervaar op die gebied van godsdienstige sosialisering en identifikasie, het 'n direkte negatiewe gevolg vir bulle identiteitsvorming. Scherzberg (1995:79) stel dit so: 'Männlichen Menschen steht trotz aller Unterschiedenheit zwischen Mensch und Gott ein männliches Gottesbild zur Identifikation offen, weiblichen Menschen ist dies nicht möglich.'

Die polarisering van die geslagte en 'n dualistiese siening van die menslike natuur dra grootliks by tot die distorsies in die samelewing, in verhoudings en in die wyse 
waarop geslagtelikheid ten opsigte van die beeld van God gebruik word. Anne-Louise Eriksson (1995:145) formuleer dit soos volg: '... (I)n order to break the theological pattem that subordinates women, we must implement a new meaning of gender in our God-talk. We need to refrain from conceptions of male and female, masculine and feminine, as binary and dichotomizing categories that separate men and women'. Om manlike en vroulike eienskappe te polariseer, manlike eienskappe as hoër, heiliger en nader aan God en vroulike eienskappe as laer, minderwaardig en nader aan die natuur te klassifiseer, is 'n sosio-kulturele produk (kyk Joan Laird 1989:430; Riet Bons-Storm 1996:50-55).

Sosialisering in die dominante patriargale 'sosio-kulturele narratief' beteken dat vroue skuldig en skaam voel wanneer hulle nie die rolle speel wat aan hulle toegeken is nie. Die 'sosio-kulturele narratief' wat die vrou implisiet of eksplisiet verneder, word deur die evangeliese 'kontra-narratief' oor God se koms in en deur Jesus weerspreek. So ook het die heersende Godsbeeld dikwels meer te doen met die sosio-kulturele narratief as met die evangelie.

\section{BEPERKTHEID EN VOORLOPIGHEID VAN BEELDSPRAAK}

Mary Daly (1973:28-31) dui aan watter manifestasies van 'n patriargale God in die hedendaagse kerklike kultuur gesien kan word. God word dikwels voorgestel as een wat straf en wat sonde oordeel volgens die norme van die heersende kultuur. Die 'almagtige Vader' word as hoof van die patriargale orde ingespan (Bührig 1993:61). In die godsdiens en erediens maak die taal en begrippe God dikwels tot patriarg. In sy hande is alle mag, beheer en krag. Die Vader sorg. Sorg word normaalweg gestereotipeer as 'n vroulike eienskap. Maar die patriarg se sorg is anders as 'n vrou se versorging. Hy sorg in die sin dat hy al die besluite en beslissings self neem. Hy regeer en oefen mag uit om seker te maak dat sy kinders kry wat hulle nodig het. Die bedoeling van die patriarg is natuurlik goed. As hy straf, is dit 'uit liefde' en tot die mens se beswil. Net hy weet wat goed is vir mense. Die Vader ly pyn as sy seun doodgemaak word. Sy woede vlam op wanneer sy kinders ongehoorsaam is en daarmee die plan wat hy vir die hele geloofsfamilie gehad het in die wiele ry deur hulle ondankbaarheid, ontrou, gebrek aan vertroue en lojaliteit. Net die Vader het die mag om te oordeel, te herstel, te verlos want hy ken die mens en weet wat die beste is. Hy is die norm. Vroue en kinders is marginaal (Eriksson 1995:146-147). Dorothee Sölle (1996:154) verwoord die probleem wat so 'n Vader-beeld vir vroue kan hê, soos volg:

My difficulties about God as Father, begetter, ruler and the manager of history grew as I began to understand more clearly what it means to be born a woman, and therefore 'incomplete', and so to have to live in a 
patriarchal society. How could I want power to be the dominant characteristic of my life? And how could I worship a God who was only a male?

Die vraag is egter of die strukture, reëls en regulasies waarmee daar oor vroue se lewens geheers word en waarmee vroue beperk en ingeperk word, deur God ingestel en so verorden is, en of dit die maaksels is van mense wat die mag het om te domineer en die wette en reëls te maak en af te dwing waarmee hulle eintiik hulle eie belange dien. Rosemary Radford Ruether (1997:37) stel dit so:

Religion, specifically the Christian tradition with its roots in the Hebrew and Greco-Roman worlds, has been faulted as a prime source of the cultural-symbolic patterns which have inferiorized women and nature. The patriarchal God of the Hebrew Bible, defined as outside and over against the material world as its Creator and Lord, when fused with Greek philosophical dualisms of spirit and matter, is seen as the prime identity myth of the Western ruling class male. He has made this God in the image of his own aspiration to be both separate from and ruling over the material world, as land and animals or non-human 'resources', and as subjugated groups of humans.

Geen mens het ' $n$ korrekte, akkurate begrip van God nie. Alle Godsbeelde is subjektief en menslike konstrukte. As sodanig is dit nodig om sowel individuele as korporatiewe Godsbeelde voortdurend te analiseer, sodat daar 'n bewuswording van distorsies en die skadelike gevolge wat daaruit voortspruit, kan posvat. Bewuswording van wat onvolmaak is, bring die mens weer by die evangelie as die bron en toetssteen van mense se kennis en begrip van God. Die toegang tot die evangelie is vir die Reformatoriese teoloog die Skrif. Die Skrif vertoon 'n groot verskeidenheid beelde van God en beelde wat vir God gebruik word. In die Skrif kan gesien word hoe sekere beelde in sekere tydperke dikwels gebruik is en in ander tye glad nie meer nie.

Die vraag is hoe gelowiges oor God en met God kan praat op 'n wyse wat nie eksklusief manlik is nie, maar tog wel Skriftuurlik verantwoord is (kyk Van Wijk-Bos (1995:ix). Dit sou nie deug om die distorsies van manlikheid en vroulikheid wat in die hedendaagse kultuur anwesig is op die Skrif te projekteer nie (kyk Martin 1994:251). Die Bybel moet gesien word binne eie konteks. Daar is uiteraard 'n beduidende afstand tussen hedendaagse mense en die mense van die Bybelse tyd. Om die Bybelteks te ver- 
staan en daarby betrokke te raak, is dit nodig om die geloofsgemeenskap van die tyd te verstaan. Daar is dus diskontinuiteit tussen ons en die Bybel. Aan die ander kant is daar egter ook kontinuiteit en verbondenheid. Wanneer ons vra hoe die gemeenskappe van die verlede gepraat het oor God en hoe dit hulle identiteit gevorm het, soek ons in werklikheid na maniere om te praat oor God en oor ons eie identiteit, en oor God se doel vir ons lewe. Wanneer ons as gelowiges soek na 'n beter verstaan van God, onsself en ons wereld, benader ons die Bybel as God se boodskap vir ons lewe, terwyl ons weet dat dit getuienisse van onvolmaakte mense bevat wat binne onvolmaakte menslike sosiale strukture geleef en gefunksioneer het.

Om oor God te probeer praat, is 'n saak wat mense tot beskeidenheid dwing. Niemand ken God se naam en het God se wese in woorde vasgevang nie. God se naam is onmoontlik om uit te spreek. In Eksodus 3:14 is God se 'naam' in Afrikaans vertaal met 'Ek is wat Ek is'. Die tradisie verstaan hierdie teks as 'n aanduiding van die onveranderlike, misterieuse aard van God se wese. Johanna van Wijk-Bos (1995:94) meen dat die werkwoordvorme wat hier gebruik word, normaalweg in die toekomende tyd vertaal sal word, naamlik 'Ek sal wees wat Ek sal wees'. Martin Buber (1958:52) onder andere, het uitgewys dat die Hebreeuse werkwoord 'does not carry a meaning of pure existence. It means: happening, coming into being, being there, being present, being thus and thus; but not being in the abstract sense'. Dit lyk dus asof Griekse grammatika en filosofie die vertaling hiervan beïnvloed het in 'n rigting wat nie die bedoeling van die Hebreeus was nie. In die konteks van die Hebreeuse taal en denke, word van God gepraat in verband met God se relasie tot die skepping. God se wese buite hierdie relasie om, is nie vir die skrywers van die Ou Testament van belang nie.

Die stelling in Eksodus 3:14, 'Ek sal wees wat ek sal wees', gaan oor God se wese en oor God se relasionele kwaliteit. Om die twee te skei veroorsaak 'n verengde verstaan van wat die teks wil oordra (Van Wijk-Bos 1995:94-95; vgl ook Johnson 1994: 224-245). Die doel is nie om 'n naam vir God te verskaf nie. Hierdie 'naam' vir God toon aan dat dit nie moontlik is om 'n naam vir God te gee nie. Die naam wat gegee word vir God, JHWH, is onuitspreekbaar. Israel moet dus uit Egipte vertrek met vertroue in 'n teenwoordigheid wat hulle nie kan benoem nie. Die misterie van God kan nie vasgevang word in 'n naam, in 'n konsep of in 'n reeks konsepte nie. Ons kan egter nie anders praat as in woorde en konsepte nie. Buber (1958:52) vertaal dit: 'I will be present as I will be present'. Wanneer dit weergegee word met 'Ek is wat Ek is', gaan die dinamiese kwaliteit en die oopheid na die toekoms verlore. 'Ek sal wees wie Ek sal wees' beteken dat die gesprek oor hoe 'n mens oor God kan praat, nooit afgesluit is nie. Dit dring mense om voortdurend hulle spreke oor God nuut te verbeeld, sodat verstarde beelde nie afgodsbeelde word nie. 
Die Bybel praat op verskillende maniere oor God se nabyheid en gebruik terme wat algemeen bekend is vir mense binne hulle kultuur. Daar word byvoorbeeld gepraat van God se hande en voete, oë en mond. God stap, sit en woon. God lag, is kwaad en is jammer. Maar die Bybel praat ook oor God op maniere wat dui op die misterie en andersheid van God. Jesaja 40-55 praat oor die onvergelyklikheid van God, maar ook oor God se nabyheid (kyk Van Wijk-Bos 1995:11). In 'n kultuur waar die mense met mag almal manlik was, sou outeurs wat God wou vereer, dit doen deur van beelde gebruik te maak wat in die kultuur van die tyd as eerbaar en waardig beskou is. In die leefwêreld van die Bybel was konings, familiehoofde (patriarge), meesters, militère leiers en regters mense met mag, eer en status. As die kultuur van die tyd, die onsigbaarheid, stemloosheid en lae status van vroue in ag geneem word, is daar reiatief baie vroulike beeide in die Bybel (Mollenkott 1992:90; vgl ook Mollenkott 1983). Israel het geleef in die teenwoordigheid van God. God was betrokke in hulle geskiedenis, het ingetree vir hulle, het 'n verbond met hulle gesluit en getrou gebly aan die verbond. In hulle gesprek met mekaar oor God het hulle baie simbole, metafore en analogieë uit hulle leerwêreld geneem om hulle ervaring van God te beskryf. Hierdie menslike simbole, metafore en analogieë is aanduiding van 'n verhouding tussen Israel en God. God is nie onbetrokke by mense nie (kyk Coll 1994:32).

' $n$ Beeld is anders as die werklikheid waarna dit verwys. Mense is gebonde aan die beperkings van taal wanneer hulle oor God praat. Alle spreke oor God, insluitend die Bybel se spreke, is gewortel in menslike ervaring. Taal werk as 'n vergelyking. So byvoorbeeld is die uitdrukking 'God is koning' 'n vergelyking tussen God en 'n menslike figuur wat in die samelewing 'n bekende sosiale posisie en funksie vervul. Met spreke oor God loop die mens altyd die gevaar om God te sien as gelyk aan hoe mense oor God praat. Dit sou wees om God vas te vang in menslike begrippe. Daarom is dit noodsaaklik om te alle tye bewus te wees daarvan '... that language for God is language of comparison and not of identification' (Van Wijk-Bos 1995:35; vgl ook Caird 1980:144; McFague [1982] 1985; Johnson 1994:113; Wren 1989:84-110; Soskice 1985).

Metafore is dus nie definisies of beskrywings nie. Hulle sê iets, maar nie alles oor die persoon of saak waaroor die vergelyking gaan nie. Vir spreke oor God bied beeldspraak dus moontlikhede, maar daar is ook beperkings inherent aan beelde en aan taal wat nie uit die oog verloor mag word nie. Omdat beelde en vergelykings uit menslike ervaring geneem word en die wêreld van mense voortdurend aan die verander is, sal beelde noodwendig ook verander. Beelde en simbole kry nuwe betekenis wanneer mense se ervaring verander. Sommige beelde en simbole verioor hulle betekeniskrag en verdwyn. 'Symbols die because they can no longer produce response in the group 
where they originally found expression (Tillich 1957:431). Metafore wat in die verlede kragtige beelde was, kan in latere tye hulle krag verloor. Beelde soos 'heer', 'koning' en 'soldaat' het nie meer dieselfde betekenis as wat hulle in die antieke tyd gehad het nie. Om te erken dat sekere metafore wat in die Bybel voorkom, deesdae as onbruikbaar beleef word, is nie 'n ontkenning van God nie maar 'n erkenning van hoe taal in die lewens van mense werk. Ander meer relevante beelde, simbole en metafore word gebore uit die ervaring van die gemeenskap (Coll 1994:40, 44).

Wat betref die korrelasie tussen die heersende Godsbeelde en vroue se identiteit en moontlikheid tot outentieke lewe voor God, het 'n paar sake in die ondersoeke hierna aan die lig gekom:

* 'n Eensydig manlike spreke oor God ontneem vroue die geleentheid tot identifikasie wat mans het en benadeel hulle sosialisering en identiteisvorming.

* Sommige beelde vir God het in die moderne tyd irrelevant geword omdat die ervaring en wêreld verander het.

* Sommige beelde vir God het problematies geword vanweë negatiewe ervarings in die moderne samelewing wat negatiewe konnotasies aan die beelde heg.

Aan die eerste punt het èk vroeër in hierdie gedeelte reeds aandag gegee. Die volgende twee punte wil ek kortliks aan die hand van drie van die mees gebruikte beelde in kerke vandag bespreek, naamlik die beelde 'koning', 'here' en 'vader'. Daar is reeds in die Bybel voorbeelde van beelde wat verander soos wat omstandighede en die ervaring van mense verander. Een so 'n voorbeeld is die titel 'koning'. Hierdie beeld vir God kom nie in die eerste vyf boeke van die Bybel voor nie. In dié tyd het Israel nie self konings gehad nie en hulle ervaring van die konings van die buurvolke was waarskynlik nie positief nie. Wanneer hulle egter koningskap ervaar, word dié beeld vir God aangewend. 'Clearly, as experience changes, designations for God change' (Van Wijk-Bos 1995:38).

\section{GOD AS 'KONING' EN 'HERE'}

'Koning' en 'Here' as aanduidings vir God kom uit dieselfde ervaringsveld. Die woorde is aanduiding van 'n manlike persoon met sosiale status wat mag uitoefen oor sy omgewing. 'Koning' dra die grootste gewig en verwys na die meeste mag. Dit dui op sowel 'n administratiewe funksie as op die status van die persoon. Om 'n godheid 'koning' te noem, was algemeen in die antieke Midde-Ooste. Maar 'koning' was nie 
die mees algemene beeld vir God in die Ou Testament nie. Dit kom sowat 40 keer voor in 'n hele aantal Psalms, Jesaja 43:15, Jeremia 8:19, Sefanja 3:15 en Miga 2:13. Die bron van hierdie beeld is mense se ervaring van menslike konings. Konings se mag en heerlikheid is eienskappe wat ook met God geassosieer word. Daar is, soos met alle beelde, egter ook aspekte van koningskap wat nie op God van toepassing is nie. God sorg vir mense terwyl aardse konings mense dikwels nie goed behandel nie. Die beeld 'koning' as aanduiding vir Jesus Christus of God (buiten die verwysings deur Jesus in sy gelykenisse) word selde in die Nuwe Testament gebruik. Daar is die mees algemene titel 'kurios', 'here' (kyk Van Wijk-Bos 1995:38-40). 'n Beeld soos 'koning' sê nie net iets oor God nie, maar ook oor die geloofsgemeenskap se verhouding tot God. Waar God koning is, is die mense onder God se sorg en beskerming. Die gelowiges gaan dus direk na God toe vir hulp. Dit was belangrik in die tyd van die Romeinse heerskappy. Die titel 'here' het ook te doen met 'n man van hoë status van wie mense met minder sosiale status in baie opsigte afhanklik is. Nie net mense met minder sosiale status het 'n man met hoër status aangespreek as 'heer' nie, maar ook die menslike besittings van die man, naamlik sy slawe, vrou(e) en kinders.

Vandag kan 'koning' en 'here' as titels vir God problematies wees. Hulle is eksklusief manlike beelde wat vroue uitsluit. Dit veroorsaak dus 'n skeef getrekte, eensydig manlike beeld van God en gee vroue niks om mee te identifiseer nie, veral nie as uitsluitlik hierdie beelde in kerke gebruik word nie. Die konteks van waaruit die beelde kom, is ook nie meer geldig nie. Konings en here is nie meer deel van baie moderne mense se ervaring nie. Die naaste ervaring wat die meeste mense vandag'van koningskap het, is die enkele oorblywende monargieë in die wêreld. Daar is geen twyfel dat die moderne ervaring van koningskap baie min te doen het met die soort koningskap van waaruit die beeld van 'koning' wat op God toegepas is, ontstaan het. 'Heer' is vir moderne mense volledig onbekend. Die naaste wat ons daaraan ken, is die woord 'baas' en dit het 'n uiters negatiewe konnotasie in die hedendaagse kultuur. 'Koning' en 'heer' is dus anakronistiese beelde wat nie vir ons tyd relevant is nie. In die moderne wêreld funksioneer hierdie beelde alleenlik in die religieuse sfeer. Dit beteken dat hulle totaal afgesny is van menslike ervaring. Die gevolg hiervan is dat die beelde hulle vergelykende krag verloor en die gevaar bestaan dat hulle al hoe meer letterlik verstaan kan word as God se naam, wie God is, wat God se wese en identiteit is. Hierbenewens het ek daarop gewys dat Jesus reeds in die Bybelse tyd die strekking van God as 'koning' disassosieer het met die gebruiklike verstaan wat dit in daardie leefwêreld gehad het. 


\section{GOD AS 'VADER'}

Naas 'Here' is seker die mees algemeen gebruikte beeld vir God dié van 'vader'. Hierdie beeld kom nie dikwels in die Ou Testament voor nie, maar relatief baie in die Nuwe Testament. Wanneer 'vader' wel in die Ou Testament gebruik word, is dit deel van ' $n$ versameling beelde geneem uit die familielewe, hyvoorbeeld God as bruidegom in die steek gelaat deur sy bruid (Jer 2:1vv), as man wie se vrou hom verlaat het (Hos 2:14vv) en as vader wie se kinders dislojaal was (Deut 32:6; Jer 3:19). In die Nuwe Testament word sulke versamelings van familiebeeld nie meer gebruik nie. God is 'ons Vader' of 'my Vader' in Jesus se taalgebruik. Maar ook hier verander Jesus radikaal die verwysing van wat mense van die 'eerbare' rol van 'n vader gehad het wanneer hy byvoorbeeld in die gelykenis van die verlore seun (Luk 15:11-32) die vader onkonvensioneel laat optree. Die beelde van God as 'ouer' of as 'eggenoot' kom uit die ervaring van patriargale familieverhoudings (kyk Van Wijk-Bos 1995:42). Maar ook hier word daar in 'n sekere sin in kontranarratiewe soos Esegiël 16:62 en Hosea 11:9 teen die konvensie (die sosio-kulturele meesternarratief) ingegaan wanneer die profete sê dat God eggenoot is anders as wat die kultuur voorskryf. In Hosea 11:9 laat die profeet, teen die agtergrond van die beeld waar verwag sou word dat die man as eggenoot geweldadig teen sy vrou sou optree, God sê: '... Ek is God, nie 'n man nie [lo'$i \$ h]$. Ek is die Heilige wat by jou is, Ek sal nie met woede ingryp nie'.

Vandag word 'n patriargale familieverhouding steeds beleef as ' $n$ instelling wat die potensiaal tot geweld en gewelddadigheid het. Sulke beelde kan daarom problematies wees vir kinders wat verwaarloos, misbruik of aangerand is/word in hulle familie. Hierdie beelde het dus wel 'n verbinding met hedendaagse ervaring, maar dit hét 'n negatiewe konnotasie bygekry. 'n Verdere probleem vir hedendaagse gelowiges is dat die beeld die gelowige in ' $n$ kinderrol plaas. Dit is veral skadelik vir vroue wat nodig het om hierdie spesifieke stereotipe te ontkom. Hoewel die vader-beeld positiewe eienskappe soos aanvaarding, liefde, versorging en veiligheid uitdruk, kan dit nie met betrekking tot wederkerigheid, volwassenheid, samewerking, verantwoordelikheid en resiprositeit gesê word nie (kyk Coll 1994:43). Dit is dus ook, soos alle beelde, een met beperkings. 'n Verdere probleem rakende die teenswoordige gebruik van die vaderbeeld in kerke is dat dit feitlik eksklusief gebruik word. Die gevolg is dat die metaforiese element daarvan verlore gaan en dat dit letterlik opgeneem word. 'By excluding other relationships as metaphors, the model of father becomes idolatrous, for it comes to be viewed as a description of God' (McFague 1987:97; vgl ook Coll 1994:41). Indien die feit dat dit as metafoor in die Bybel gebruik is, uit die oog verloor word, word ook die disassosiatiewe strekking daarvan in Jesus se taalgebruik nie meer raakgesien en benut nie. 
In die Bybel word die beeld 'vader' uiteraard baie positief bedoel. Dit is ook vandag steeds 'n belangrike beeld vir God, veral gesien in die lig van Jesus se gebruik daarvan. Daar sal egter ook gekwalifiseer moet word wanneer en hoe die beeld gebruik word. Oor hoe die beeld gebruik behoort te word, is die Bybel duidelik: 'In reviewing Scripture's use of the paternal image for God, we found that the Bible reserves language of family life for the expressions of God's deepest and tenderest love for the people and of God's vulnerability in the face of this love' (Van Wijk-Bos 1995:44; vgl ook Pruett 1994:87-103). Die gelykenis van die verlore seun 'n goeie voorbeeld van die weerloosheid van God se vaderliefde. Deur die seun wat die eer van die vader volgens kulturele konvensie geskend het, met oop arms terug te ontvang en hom nie te straf sodat die vader se eer herstel kan word nie, verioor die vader verder eer in die oë van die samelewing. Ook die wyse waarop die vader hom tegemoet gehardloop het, sou nie beskou word as waardige gedrag vir 'n patriarg in die samelewing nie. In sy liefde vir die seun, het die vader dus sy eer (in daardie samelewing so belangrik soos die lewe self) op die spel geplaas. Selfs wanneer die vader sy terugkerende 'verlore seun' soen en met 'n maaltyd versorg, word die eksklusiewe manlike rol volgens Bernard Brandon Scott met vroulike elemente gerelativeer: 'The father combines in himself the maternal and paternal roles. As a father he is a failure, but as a mother he is a success. It is his forgiving, nourishing character that has entranced generations of hearers and readers' (Scott 1990:122).

Soos ek reeds met verwysing na Esegiël en Hosea daarop gewys het, sal daar ook gekwalifiseer moet word dat God nie soos ' $n$ menslike vader is nie. Hedendaagse mense se ervaring van 'vader' is dikwels dié van 'n swakkeling, of 'n koue, harde, ongenaakbare, ontoeganklike persoon, of ' $n$ afwesige, onbetrokke vader van wie hulle geen versorging ontvang nie, of selfs 'n verkragter en aanrander van sy vrou of kind(ers) (vgl Herman 1981; Armstrong 1978; Russell 1984, 1986). God oefen nie op sulke maniere beheer uit nie en is nie gewelddadig nie. God se liefde is weerloos, teer en heelhartig (vgl Hos 11:14). Al hierdie dinge is nie uitsluitlik manlike eienskappe nie, daarom hoef daar nie 'n uitsluitlik manlike beeld gebruik te word vir ouerliefde nie. McFague (1987:122) stel dit so: 'God as mother does not mean that God is mother (or father). We imagine God as both mother and father, but we realize how inadequate these and any other metaphors are to express the creative love of God, the love that gives, without calculating the return, the gift of the universe.'

\section{NIE-PATRIARGALE GODSBEELDE}

In pastoraat met vroue is dit noodsaaklik om vas te stel wat vroue se konnotasie is met beelde wat vir God gebruik word. Indien negatiewe ervarings van 'vader' vroue se er- 
varing van God belemmer, sal die pastor wat verdere skade wil verhoed, nie op 'n rigiede wyse aan die geykte beelde wat in die meeste kerke feitlik uitsluitlik gebruik word, vashou nie. Dit sou van die pastor vra om fyn te luister na positiewe beelde wat vroue self gebruik en daarop in te speel. As die vrou self nog nie kreatief met Godsbeelde kan omgaan nie en juis vanweë die geykte beelde in 'n impasse beland, kan die pastor kreatiwiteit met Godsbeelde modelleer totdat die vrou bevryding en 'n outentieke relasie met God beleef. 'n Pastor wat meen dat die kerk se eksklusiewe metafore werklik God se naam is of God se wese beskryf, sal nie hiertoe in staat wees nie.

Wat pastorale interaksie met vroue in die algemeen betref en nie net pastorale berading nie, is kreatiwiteit met Godsbeelde ook belangrik. Ek het reeds die skade uitgewys wat ontstaan as gevolg van die eksklusiewe gebruik van manlike beelde vir God, asook die gevaar wat dit inhou wanneer die beelde beskou begin word as ' $n$ aanduiding van God se naam of identiteit. Vanwee laasgenoemde rede is dit in elk geval ter wille van die leer van die kerk belangrik om 'n groter verskeidenheid beelde vir God te gebruik as net 'vader' en 'heer'. Vanweẽ die veranderde wêreld en menslike ervaring is dit noodsaaklik vir die hele geloofsgemeenskap dat relevante beelde gebruik word. Om die oorweldigende manlikheid van alles wat in die kerk belangrik is, ietwat te neutraliseer is dit vir vroue in die besonder belangrik dat 'n veelvoud van Bybelse beelde vir God gebruik sal word. Hierdie beelde kan geslagsneutrale en vroulike beelde insluit. Hoewel ' $n$ kreatiewe omgaan met beelde vir God seker nie tot die Bybel beperk hoef te word nie, is sulke beelde wel in die Bybel te vinde. Vir vroue is niemanlike beelde belangrik ter wille van hulle identifikasie en sosialisering binne die geloofsgemeenskap, ascok die ontwikkeling van 'n goed omlynde identitet as 'n menswaardige persoon en waardige, volle lid van die geloofsgemeenskap. Teenoor die vroue in Europa en Noord-Amerika wat die kerk vaarwel geroep het, is daar tog 'n groep wat die hoop het dat daar wel ruimte is vir volle menswaardigheid vir vroue binne die ruimte van die kerk en die Christelike geloof. 'For us, our faith and the God of our faith are neither so rigid nor so tied to one type of language that they cannot stand adaptation and change', meen Johanna Van Wijk-Bos (1995:7). Sy pleit vir wyses om te praat oor God op maniere wat transformasie en verandering in die gemeenskap in die rigting van groter inklusiwiteit meebring.

Die gebruik van ' $n$ verskeidenheid beelde of metafore vir God gee erkenning aan die feit dat God soveel meer is as enigiets wat mense cor God kan sê. Dit herinner aan die gans-andersheid van God en die kleinheid van eie menslikheid (vgl Coll 1994:41; Scherzberg 1995:80). Taal behoort vroue nie vir altyd uit te sluit nie. Die kerk kan 'n poging aanwend om meer inklusief te praat, ook wat beelde betref. Die lewende God kan nie vasgevang word in beelde nie, en 'certainly not [in] a purely male-fashioned 
image' (Bührig 1993:63,65). Ook die Britse teoloog Brian Wren (1989:132) is 'n voorstander van 'n verskeidenheid beelde vir God. Hy wys daarop dat die beelde nie noodwendig met mekaar versoenbaar hoef te wees nie. Inteendeel, die ontoereikendheid van beelde wat deur onversoenbaarheid geillustreer word, dui juis op die grootheid van God wat mense probeer benoem:

Linguistic images are more fleeting [than graven images] and leave room for imagination ... No image is adequate. To select one image and bow down to it is idolatrous. If we draw on a variety of God-images, and let them balance, enrich, and clash with one another, we shall be following the instincts of biblical faith and the methods of many biblical voices. Allowing God-images to clash is important, because it reminds us that we are approaching that which is beyond all images ... [As we look at the biblical record], it is fair to speak of a direction of divine action, seeking to undermine and overthrow patriarchal structures ... The King abandons his throne, calls his disciples friends, and washes their feet. The Spirit creates a community uniting gentiles and Jews, slaves and free citizens, in which there is a brief glimpse of women exercising leadership with men.

(Wren 1989:132)

Ter wille van die gebruik van 'n groter verskeidenheid beelde, wil ek vervolgens kortliks aandag gee aan 'n aantal alternatiewe beelde vir God wat verder ontwikkel kan word. Die Bybel kan ondersoek word vir 'n diversiteit van geslagsneutrale beelde vir God. In die Bybel dien die hele geskape wêreld as bron vir beelde wat iets kan verduidelik van God en God se relasie met die skepping. God word onder andere in die $\mathrm{Ou}$ Testament vergelyk met 'n herder, pottebakker, beer, leeu, rots en 'n muur (vgl Mollenkott 1983; Johnson 1994:117-120). Sommige beelde word selde gebruik, ander weer meer dikwels.

\subsection{God as 'vriend'}

'n Metafoor wat goed sal inpas in die moderne tyd, wat geslagsinklusief is en wat in die Bybel voorkom, is dié van 'vriend'. Vriendskap sluit meer in as ouerskap (vaderskap). Dit sluit wel die familie ook in, maar strek verby die grense van familie. Alle menseverhoudings strewe na vriendskap. Waar daar in verhoudings nie vriendskap ook is nie, gaan hulle meesal geleidelik tot niet. Ouers en kinders kan 'n verhou- 
ding hê wat uit meer as wedersydse plig bestaan wanneer hulle ook vriende word. Broers en susters behou kontak as hulle ook vriende is. As hulle nie mekaar se vriendskap geniet nie, vervreem hulle dikwels van mekaar. As eggenote nie ook vriende is nie, word 'n huweliksverhouding 'n tragedie. Enige verhouding word verryk deur vriendskap (Coll 1994:44; vgl ook McFague [1982] 1985:177-192; 1987; Johnson 1994:235-236). Die bekendste verwysing na vriendskap in die Bybel is sekerlik Johannes 15:13, 15: 'Niemand het groter liefde as dit nie: dat hy sy lewe vir sy vriende aflê ... Ek noem julle nie meer ondergeskiktes nie, want 'n ondergeskikte weet nie wat sy baas doen nie. Nee, Ek noem julle vriende, omdat Ek alles wat Ek van my Vader gehoor het, aan julle bekend gemaak het'.

'n Hele aantal eienskappe van vriendskap kan met sukses op God toegepas word. Vriendskap is byvoorbeeld 'n geskenk. Vriende het geen regte oor of verpligtinge teenoor mekaar nie. Daar is geen dwang nie. Vriendskap word uit vrye wil gegee. Dit is 'n gawe en nie 'n plig nie. Dit kan nie liefde opeis nie. Liefde vir God as plig en gehoorsaamheid aan 'n gebod staan teenoor 'n vrywillige antwoord van liefde op God se liefde. Groter klem op die tweede as op die eerste, sal waarskynlik by moderne mense meer oortuigend werk. God dwing niemand om God se vriend te wees nie. Liefde moet vrywillig gegee word. As God gesien word as vriend, is die reaksie op sonde ook anders. Dit veroorsaak wroeging om te weet jy het ' $n$ vriend seergemaak. Dit bring pyn en 'n gevoel van verlies mee. 'n Mens voel baie jammer en spyt en neem jou voor om nooit weer die vriend seer te maak nie. Dit bring ' $n$ intense bewussyn van hoe broos en kwesbaar verhoudings is. As die vriendskapsverhouding herstel, is daar groot vreugde oor die vergifnis en die herstel.

Vergifnis kry nuwe betekenis wanneer God gesien word as vriend. As familie nie vergewe nie, bly hulle familie. $\mathrm{Al}$ is daar verder geen egte verhouding of vergifnis nie, bly daar tegnies steeds ' $n$ band tussen mense. Die vergifnis van 'n vriend is suiwer genade, 'n geskenk. As dit nie daar is nie, gaan die verhouding tot niet. Solank die verhouding dus bestaan, is dit ' $n$ outentieke relasie en nie net ' $n$ tegniese, formele band nie. Ook gebed kan anders beleef word, wanneer God gesien word as vriend. Kommunikasie is noodsaaklik om ' $n$ vriendskap in stand te hou. Kommunikasie is 'n noodwendigheid wanneer mense vriende wil wees. Hulle wil hulle vreugdes en leed met mekaar deel en hulle wil vir mekaar beskikbaar wees in tye van vreugde en pyn. Dit is liefde, en nie plig of formele bande nie, wat vriende dring om hulle verhouding in stand te hou. In 'n vriendskapsverhouding is daar nie ruimte vir ongelykheid of hiërargie nie. Die werklikheid van God in gelowiges se lewens is die hoogste uitdrukking van liefde en vryheid (kyk Coll 1994:44-47; vgl ook Moltmann-Wendel 1996). 


\subsection{God as 'moeder'}

Ook die tradisionele beelde van God as skepper en verlosser kan uitgebou word. God is die oorsprong van die skepping, van alles wat bestaan. Tradisioneel word God die skepper genoem. Die beeld van verlosser hou verband met God se bevrydende aktiwiteit. Lossing was 'n bekende sosiale gebruik in Israel. Dit het soms gepaard gegaan met koste: 'n losprys moes betaal word. So byvoorbeeld moes daar by die vrywording (lossing) van 'n slaaf 'n bepaalde loon betaal word. Die vroeë kerk het later hierdie idee op Christus toegepas. 'Verlosser' kan as 'bevryder' vertaal word. God bevry mense van slawerny, verdrukking, onderdrukking, sonde en dood. God het alles gemaak en alles het God se bevrydende aktiwiteit nodig om heelheid, genesing en shalom te kan ervaar. Die mensheid kan dit nie self regkry nie. Wie buite God se teenwoordigheid wil lewe, sal dit ontbeer. In Israel kon 'n losser net 'n man wees. Beelde van skepper en bevryder in Jesaja is egter vroulike beelde (Jes 43:1, 7; 44:2, $24 ; 45: 9,11 ; 51: 13 ; 54: 5)$. Verskillende aspekte van moederaktiwiteite word in die beelde weerspieël.

In Jesaja 42:13 word God uitgebeeld as soldaat (vgl Neufeld 1997; Washington 1997:332-352; Randall 1997) wat die oorlogskreet skree en roep en in vers 14 is God 'n vrou wat skree terwyl sy geboorte gee. Nie een van die twee is passief nie. Albei is ten volle aktief en neem deel aan wat gebeur. Die uitkoms vir albei kan die dood wees. Van Wijk-Bos (1995:50-64) wys daarop dat die twee figure ook in kontras tot mekaar staan: die soldaat vernietig die lewens van die vyand, die vrou gee geboorte aan die volk. Die effek van die beelde op die moderne hoorder, is ambivalent. Om God as soldaat voor te stel is vir die hedendaagse ervaring nie sondermeer anvaarbaar.nie, maar die idee van 'n sterk God wat intree vir mense, is vir moderne mense weer aanvaarbaar. 'n Vrou wat geboorte gee is baie nader aan algemene ervaring. Tog ervaar mense dit dikwels as 'n vreemde beeld om toe te pas op God. Moontlik het die vreemdheid van die ervaring te doen met die diep ingewortelde konnotasie van manlikheid met God asook die minagting vir die vroueliggaam, veral waar die reproduktiewe funksie ter sprake is.

Die voorbeelde in die Bybel waar God as moeder uitgebeeld word, is nie net beperk tot geboorte gee en voed nie. Daar is 'n diversiteit van beelde wat ook verbondenheid, verantwoordelikheid en versorging insluit. God as moeder onthou haar volk in hulle gebrokenheid, en maak hulle heel. God lei die mense, genees hulle en leer hulle. God as moeder is die teenwoordigheid wat tuiste simboliseer vir die mensdom. Die liefde van God as moeder skep ruimte waar mense kan optree, en waar hulle verantwoordelikheid moet aanvaar vir hulle dade, individueel en as gemeenskap. Dikwels is die spesifieke taal van geboorte gee 'weg' vertaal en besef lesers nie dat dit in werklikheid ' $n$ vrouebeeld is nie. 
Vanweë moderne ervaring, is daar egter 'n gevaar verbonde aan die gebruik van moederbeelde vir God. Elizabeth Johnson (1992:77) verwoord dit so: 'Given the patriarchal construction of motherhood, there is a danger that the mother image in speech about God, especially if it is the only female symbol used, may subtly undermine women's search for identity in their own whole person apart from the relationship and role of mothering'. Sy beklemtoon derhalwe ook die belangrikheid daarvan om 'n verskeidenheid van die beelde vir God in die liturgie, gebed en gesprek te gebruik.

'n Goeie bron vir vroulike beelde vir God word aangetref in die wyse waarop die wysheid beskryf word (vgl Martin 1994:241; Deane-Drummond 1997; Beckman 1997). In Spreuke word wysheid gepersonifieer as 'n vrou. In die Nuwe Testament word Jesus geidentifiseer met die wysheid van God (1 Kor 1:23-24; Luk 1:35). Wysheid was reeds daar voor die skepping en het 'n unieke verhouding met God: 'Proverbs 1-9 ... outlines a divine aspect disclosed in female form' (Van Wijk-Bos 1995:84; vgl ook Johnson 1994:214-215). Wysheid is 'n Goddelike eienskap en hierdie eienskap word gepersonifieer as 'n vrou. Daar word egter nie in hedendaagse kerke veel oor die gepersonifieerde wysheid gepraat nie: 'Woman Wisdom was interpreted and reinterpreted and finally became co-opted and forgotten by the patriarchal voices of the tradition. She whose voice was raised with such authority was finally silenced' (Van WijkBos 1995:86). Wysheid is ' $n$ vrou wat selfs in die antieke patriargale kultuur praat. Sy praat boonop oor haarself: wysheid. Wysheid is nie maar 'n abstraksie nie, maar 'n manier van lewe, 'n manier van wees. Wysheid beweeg tussen die markplek en die huis. Haar gesag word dus uitgeoefen buite die huis, weer eens merkwaardig genoeg binne die patriargale sisteem. Sy word nêrens uitgesluit nie.

Teenoor die positiewe vroulike beeid van Wysheid is daar in Spreuke ook sterk negatiewe vroulike beelde, naamlik van die 'slegte vrou' (Spr 2:16; 5:3- 6:5;), die listige prostituut (7:6-27) en die dwase vrou (Spr 9:13-18). 'A view of women as either superior or inferior, saints or prostitutes, is a typical patriarchal portrayal. Dividing one category of women from another, approving of one type while disapproving of the other, has been and is a politically effective strategy to keep things going as they are' (Van Wijk-Bos 1995:87). Die feit dat wysheid gepersonifieer as 'n vrou in die Bybel voorkom, bied egter wel vir moderne vroue moontlikhede: ' $(\mathrm{H})$ er presence in Scripture engages women at the point of their authority and ability to speak their reality and the reality of God' (Van Wijk-Bos 1995:88).

\section{KRISTALPUNTE}

Taalgebruik ontstaan nie net oornag nie. Dit vertoon 'n groeiproses en is op die manier altyd verbonde aan wat voorafgegaan het. Hedendaagse taalgebruik in die samelewing 
en in die kerk, asook taalgebruik oor God, het wortels in die Bybel, die geskiedenis en die tradisie. Elizabeth Johnson (1994:9) dui die verbondenheid tussen die hedendaagse praktyk en die tradisie soos volg aan:

By classical theology I mean the body of thought that arose in early Christian centuries in partnership with the Greek philosophical tradition and continued through the medieval period, molding the discourse of the churches at the beginning of the modern era. This tradition continues to shape contemporary language about God, both explicitly and implicitly, whether accepted or rejected, in popular and intellectual circles, particularly in its language about the Supreme Being, divine attributes, and trinitarian persons.

The feminist perspective, which honors women's humanity, women as imago Dei, finds this classical tradition profoundly ambiguous in what it has meant for female well-being. It has aided and abetted the exclusion and subordination of women, but also sustained generations of foremothers and foresisters in the faith.

Met die volle erkenning van hoe die tradisie lyk en dat dit nie sonder skade vir vroue was nie, is die volgende logiese vraag dié na hoe die hedendaagse praktyk verbeter kan word. Een voor die hand liggende manier om dit te doen, sou wees om aandag te gee aan die taal van die kerk in die algemeen en meer spesifiek wanneer daar.oor God gepraat word. 'n Verskeidenheid van beelde wat ook geslagsneutrale en vroulike beelde insluit, kan byvoorbeeld help om die balans te herstel sodat daar ook vir vroue lewensruimte in die kerk kan wees. 'n Ander moontlikheid op die gebied van taalgebruik, is om ook aan grammatika aandag te gee. Dit sou byvoorbeeld beteken om nie manlike grammatikale vorme te gebruik waar dit onnodig en selfs onvanpas is nie. Wanneer oor God as Vader gepraat word, is manlike voornaamwoorde gepas aangesien Vader onteenseglik 'n manlike beeld is. Jesus was ook 'n manlike persoon in die geskiedenis. Om die rede is manlike voornaamwoorde vir Jesus uiteraard gepas. Daar is egter geen rede om die Heilige Gees met 'n manlike grammatikale vorm aan te dui nie (vgl Sherzberg 1995:80). Neutrale taalgebruik ten opsigte van die Gees is wenslik ter wille daarvan om in die eerste plek nie 'n wanbegrip ten opsigte van die Gees se geslagtelikheid (of gebrek daaraan) te veroorsaak nie en in die tweede plek om vroue in die kerk nie onnodiglik te oorweldig met uitsluitlike manlikheid nie. Dieselfde geld trouens vir die woord 'God', wanneer dit sonder die verdere kwalifikasie van 'n beeld 
gebruik word. Die feit dat Bybelskrywers vanuit hulle patriargale agtergrond manlike voornaamwoorde vir God gebruik het, beteken nie dat God manlik is of dat ons vandag steeds verplig is om na God te verwys in manlike terme nie.

Wanneer 'n vroulike beeld vir God gebruik word, is 'n vroulike voornaamwoord net so gepas as wat 'n manlike voornaamwoord by die gebruik van die woord 'Vader' is. ' $n$ Voorbeeld hiervan is wanneer God beskryf word as moederhen wat haar kuikens onder haar vlerk beskerm. Wanneer die parallelle gelykenis aan die gelykenis van die verlore skaap, naamlik die gelykenis van die vrou wat die geldstuk verloor en weer gevind het, gebruik word, geld dieselfde. Hier kan gepraat word van God as 'n vrou wat so bly is om wat verlore was, weer te vind dat sy haar vriendinne nooi om saam met haar fees te kom vier.

Wanneer die hedendaagse samelewing probeer om die patriargale distorsie af te skud, kan ons onmoontlik die maniere waarop die patriargale stelsel in die Bybel gemanifesteer het, net so oorneem. Aan die een kant moet daar dus respek wees vir die Bybel en die taalgebruik van die Bybel binne konteks. Aan die ander kant moet daar respek wees vir die konteks van ons tyd. Ons praat vandag anders omdat ons werklikheid anders lyk. Vroue spreek hulle mans nie meer aan as 'my heer en meester' net omdat Sara dit met Abraham gedoen het nie. Ter wille daarvan om distorsie te vermy, behoort die manlike taalgebruik in die Bybel gekwalifiseer te word in die hermeneutiese proses en behoort die hedendaagse spreke oor God sover moontlik neutraal wees ter wille van die insluiting van alle persone teenwoordig (byvoorbeeld in ' $n$ erediens).

In eietydse taalgebruik in die kerk gaan dit nie net om beelde vir God en taalgebruik waarmee die werklikheid van God in gelowiges se lewens uitgedruk word 'nie. Taal is ook 'n faktor wat die onderlinge gemeenskap van gelowiges betref. Hierdie gemeenskap kan daarvan getuig dat dit patriargale distorsies wil regstel of in stand hou. Dit kan die tradisionele erfenis van disrespek vir vrou en vroueliggame voortsit of dit verander in 'n praktyk wat getuig van respek. Die respekvolle opsie sou byvoorbeeld insluit om nie deur taalgebruik te kenne te gee dat die erfenis van die 'manlike as die norm vir menswees' steeds voortgesit word nie. Wanneer in die prediking gepraat word van 'die gelowige' of die 'kind' en daar verder verwys word na 'hy' en 'hom' asof alle gelowiges en kinders manlike persone is, of dat vroue en dogters wat nie manlik is nie, hulle nogtans ingesluit behoort te voel by manlike terme, word die agterhaalde androsentriese erfenis lewendig gehou.

Ter wille van respek vir en die insluiting van vroue, is dit wat die spreke oor God betref, nie soveel moeite of grammatikaal so ondoenbaar om die woord 'God' gewoon te herhaal in plaas van om manlike voomaamwoorde te gebruik nie. Dit is ook nie grammatikaal 'n probleem om die meervoudsvorm of die passiewe vorm te gebruik om 
eksklusief manlike voornaamwoorde vir inklusiewe entiteite uit te skakel nie. Eweneens kan die passiewe vorm gebruik word om die voornaamwoord as sodanig waar dit oor God gaan, te vermy. Die passiewe vorm is dikwels in die Nuwe Testament gebruik om 'n oortollige gebruik van God se naam uit te skakel. Ons kan in die moderne tyd dieselfde tegniek inspan met 'n ander doel: om voornaamwoorde wat verwys na God, uit te skakel. Wanneer daar na mense verwys word, soos byvoorbeeld 'gelowiges' of 'kind', is dit ook nie onmoontlik om die meervoud te gebruik om sodoende weg te kom van manlike voornaamwoorde wat die indruk skep dat die manlike die norm vir menswees is nie.

Pastorale interaksie met vroue sluit die totale kerklike milieu in. Die situasie is nie beredder wanneer die pastor in 'n een-tot-een pastorale verhouding met 'n vrou probeer om respekvol te wees ten opsigte van taalgebruik, die gebruik van beelde vir God en respek vir die vrou se teenwoordigheid en persoonskap, maar die geloofsgemeenskap sluit vroue steeds uit of behandel hulle asof hulle onsigbaar is nie. 'n Pastorale interaksie met vroue wat vir vroue die ruimte wil bied om met God te identifiseer ter wille van hulle identiteitvorming as gelowiges en outentieke lewe voor God as volle, gerespekteerde lede van die geloofsgemeenskap, sal die volle spektrum van die kerklike lewe moet dek. En egte geloof werk soos suurdeeg in die breë samelewing.

Die pastor benader die pastorant met die Bybel in die hand. Die hermeneutiese benadering sonder ideologiekritiek objektiveer die pastorant deur haar met behulp van die Bybel stil te maak. 'n Bewuswordings- en bewusmakingsproses sal daarom na albei kante toe moet werk sodat 'n kritiese houding teenoor sowel agterhaalde kultuurpatrone in die Bybel as die geinstitusionaliseerde mens gekweek word. Ideologiekritiek is die produk van die hermeneutiek van suspisie. Die bewusmakingsproses by die pastor is gerig op die ideaal om die vrou steeds meer as 'n volledig persoon in eie reg te sien in plaas van as ' $n$ minderwaardige wese wat haar plek in die hiërargie inneem as 'n aanhangsel, ondersteuner of gebruiksartikel van 'n man. Dit sluit in om na haar te luister met die doel om haar werklik te hoor en binne haar eie konteks te verstaan, om haar te glo, om haar ervaring as outentiek te erken, ook wanneer sy self vanweë kondisionering met al hierdie dinge sukkel. Dit beteken dat die pastor 'n eerlike poging sal aanwend om haar leefwêreld te betree deur middel van invoeling, hoe vreemd dié leefwêreld ook vịr 'n manlike pastor mag voorkom. Ek het vroeër gesê dat dit 'n ongemaklike weg veronderstel. Die gemaklike uitweg is om vrouwees te stereotipeer volgens die dominante narratief.

Vif vrouepredikante kan hierdie verwysingsraamwerk, juis omdat dit so bekend is, 'n bedreiging inhou. Vroue wat predikant geword het, het die beperkings van die vroue-wêreld in 'n opsig oorstyg. Vir 'n vrouepredikant om werklik in te voel in die 
verwysingsraamwerk van 'n vrouepastorant, sal beteken dat sy soms die tradisionele vrouewêreld weer sal moet betree. Hierdie weg kan 'n angswekkende ervaring vir 'n vrouepredikant wees. Die rede is dat hierdie wêreld wat sy met moeite ontsnap het, weer 'n suigkrag op haar uitoefen. As vrouepredikante nie bewus geword het van hulle eie ambivalensie ten opsigte van vrouwees en 'n weg daarmee gevind het nie, kan dit in die pad kom van egte pastorale kommunikasie met 'tradisionele' vroue.

Waar die vrouepastorant se gebrekkige persconskap en nie-identiteit simmetriese kommunikasie in die wiele ry, sal die pastor voorlopig sterk leiding moet neem in die bewusmakingsproses by vroue. Die pastor sal vroue begelei om te kom tot aanvaarding van hulle God-gegewe waarde as volwaardige mens, tot 'n volwasse, eie identiteit en 'n egte ervaring van hulle persoonskap. Dit kan in die meeste gevalle 'n lang proses wees. Omdat pastors hierin 'n leidende rol speel, sal hulle daarteen moet waak om nie 'n paternalistiese kommunikasiestyl te handhaaf of om die rol van die 'kundige', soos in die mediese model, te speel nie. Hoewel die pastorant tydelik afhanklik is van die pastor se leiding, bly die einddoel hulle volwaardige funksionering as mede-subjekte binne die interaksie. Die begeleidingsproses sal sake soos hulle gevoel van eiewaarde en selfvertroue, vertroue in hulle eie gevoel, oordeel, mening en ervaring, asook die artikulasie van hulle eie ervaring insluit. Daar is soms heelwat blokkasies op al hierdie terreine in die geïnstitusionaliseerde leefwêreld van vroue. $\mathrm{Na}$ die pastorale gesprek keer vroue terug na 'n leefwêreld waar van hulle verwag word om die tradisionele rol te vervul. Die gevolg is dat die positiewe resultaat van die pastorale interaksie dikwels afgebreek word.

Deel van die pastorale interaksie is die pastor se taak om die pastorant bewus te maak van haar rol as beelddraer van God. Indien dit duidelik word dat vroue se Godsbeeld van so ' $n$ aard is dat dit hulle reduseer tot nie-identiteit en hulle verhinder om outentieke lewe voor God te ervaar, is dit nodig om aan die beelde wat van God en vir God gebruik word, aandag te gee. Ek het vroeër uitgewys hoe Godsbeelde ingespan is om vroue minderwaardig te maak en aan hulle onbenydenswaardige rolle en take toe te ken. Vroue vind psigologies allerlei weë om sulke Godsbeelde te versoen met die evangelieboodskap oor die liefdevolle en genadige God wat mense in Jesus van Nasaret ervaar het. Hulle probeer hierdie twee teenoorstaande idees van God harmonieer omdat dit in die tradisionele narratief aan hulle voorgehou word as die werklikheid oor God en oor hulle vrouwees. Aangesien die twee sake wat hulle probeer harmonieer egter in wese nie met mekaar versoenbaar is nie, het ons met botsende narratiewe te doen. Dit was die leemte wat ek uitgewys het toe ek in die praktykteoretiese bespreking aan die storiemodel aandag gegee het. Ek kon nie aanvaar dat daar van die pastorant verwag word om vrede te maak met haar ervaring van nie-identiteit omdat dit sou bots met 
die Bybel as die oorkoepelende makro-narratief nie. Die pastor het hier ' $\mathrm{n}$ taak om die pastorant bewus te maak van meester- en kontranarratiewe in die Bybel. Indien dit nie gebeur nie, word die botsing deur die pastorant beleef as 'iets verkeerd met $m y$ '. Vroue ontken en onderdruk dan hierdie konflik omdat dit nie as 'behoorlik' beleef word nie. Ontkenning en onderdrukking vererger egter die innerlike spanning en lei dikwels tot depressie - en, erger nog, tot 'n gebrek aan outentieke lewe voor God.

Die essensie van die probleem is dat die Godsbeelde van die dominante narratief gelyk gestel word aan wie en wat God is en wat God wil hê. Op hierdie struktuur het vroue hulle (nie-)identiteit, hulle lewe en hulle verhouding met God gebou. Wanneer 'n hermeneutiek van suspisie hierdie mensgemaakte strukture en hulle onderliggende belange blootlê en dit skei van God se wil en bedoeling met die mens, kan vroue dit as bevrydend en 'n groot verligting beleef. Die pastor het die taak om die pastorant bewus te maak dat daar in die Skrif ook beelde vir God gebruik word waarmee vroue hulle kan identifiseer. Godsverduistering word weggeneem en outentieke lewe kom in die plek daarvan. Indien die pastor nie hierdie taak uitvoer nie, kan die gevolge vir vroue traumaties wees wanneer die hele bekende struktuur waarop hulle lewens en geloofsverhoudings gebou is, in duie stort. Dit is vervolgens nodig dat die pastor en vroue saam opbou aan 'n nuwe struktuur en verwysingsraamwerk waarbinne outentieke vroue-spiritualiteit onbelemmerd ervaar kan word.

\section{Literatuurverwysings}

Armstrong, L 1978. Kiss daddy goodnight. New York: Seaview Books.

Bach, A 1998. Rereading the body politic: Women and violence in Judges 21, Biblical Interpretation: A Journal of Contemporary Approaches 6/1, 1-19.

Beckman, N E 1997. Sophia: Symbol of Christian and feminist wisdom? Feminist Theology 16, 32-54.

Beukes, C J 1996. Michel Foucault en die historisering van Anderswees. HTS 52/2\&3, 233-251.

Bonhoeffer, D 1967. Letters and papers from prison. London: SCM.

Bons-Storm, $R$ 1996. The incredible woman: Listening to women's silences in pastoral care and counseling. Foreword by P D Couture. Nashville: Abingdon Press.

Buber, M [1953]:1988. Eclipse of God. Studies in the relation between religion and philosophy, with an introduction by Robert M Seltzer. Atlantic Highlands, NJ: Humanities Press International.

1958. Moses: The revelation and the covenant. New York: Harper \& Row. Bührig, M 1993. Woman invisible: A personal odyssey in Christian feminism. Valley Forge, PA: Trinity Press International. 
Caird, G B 1980. The language and imagery of the Bible. Philadelphia: Westminster. Carr, A 1988. Transforming grace. San Francisco: Harper \& Row.

Coll, R A 1994. Christianity and feminism in conversation. Mystic, CT: TwentyThird Publications.

Daly, M 1973. Beyond God the Father: Toward a philosophy of women's liberation. Boston: Beacon.

1979. Gyn/Ecology: The metaethics of radical feminism. Boston: Beacon.

Dean-Drummond, C 1997. The feminine face of God as a metaphor for an ecotheology. Feminist Theology 16, 12-31.

Die berymde psalms saam met die evangeliese gesange 1978. Kaapstad: NG Kerk Uitgewers.

De Pater, W A 1996. Het postmoderne nog eens uitgelegd. Nederlands Theologisch Tijdschrift 50/3, 177-202.

Dreyer, Y 1998. Pastorale interaksie met vroue: 'n Prakties-Teologiese begronding. DD-proefskrif, Universiteit van Pretoria.

Dreyer, Y 1996. Bybelse huweliksrolle en die moderne egalitêre huwelik (Efes 5:2132). Praktiese Teologie in Suid-Afrika 11/2, 95-103.

Eriksson, A-L 1995. The meaning of gender in theology: Problems and possibilities. Stockholm: Gotab. (Women in Religion 6.)

Herman, J 1981. Father-daughter incest. Cambridge, MA: Harvard University Press. Johnson, E A 1994. She who is: The mystery of God in feminist theological discourse. New York: Crossroad.

Laird, J 1991. Women and stories: Restorying women's self-constructions, in McGoldrick et al (ed), Women and families: A framework for family therapy. New York: Norton.

Martin, F 1994. The feminist question: Feminist theology in the light of Christian tradition. Grand Rapids, MI: Eerdmans.

McFague, S [1982] 1985. Metaphorical theology: Models of God in religious language. Philadelphia: Fortress.

1987. Models of God: Theology for an ecological, nuclear age. Philadelphia: Fortress.

Mollenkott, V R 1983. The divine feminine: The biblical imagery of God as female. New York: Crossroad.

1992. Sensuous spirituality: Out from fundamentalism. New York: Crossroad.

Moltmann-Wendel, E 1996. Motherhood or friendship, in Schüssler Fiorenza, E (ed), The power of naming: A Concilium reader in Feminist liberation theology, 292299. Maryknoll, NY: SCM. 
Neufeld, T R Y 1997. Put on the armour of God: The divine warrior from Isaiah to Ephesians. Sheffield: Sheffield Academic Press. (JSNT Supplement Series 140.)

Pruett, G E 1994. As a father loves his children: The image of the Supreme Being as loving father in Judaism, Christianity and Islam. Bethesda, MD: International Scholars Publications.

Randall, A B 1997. From the warrior God YAHWEH to the creator God ELOHIM. Explorations: Journal for Adventurous Thought 16/1, 43-60.

Ruether, R R 1997. Ecofeminism: First and third world women. American Joumal of Theology \& Philosophy 18/1, 33-45.

Russell, D E H 1984. The prevalence and seriousness of incestuous abuse: Stepfathers v. biological fathers. Child Abuse and Neglect: The International Journal 8, 15 22.

1986. The secret trauma: Incestuous abuse of women and girls. New York: Basic Books.

Scherzberg, L 1995. Grundkurs feministische theologie. Mainz: Matthias-GrinewaldVerlag.

Schüssler Fiorenza, E 1996b. For women in men's world: A critical feminist theology of liberation, in Schüssler Fiorenza, $\mathrm{E}$ (ed), The power of naming: A Concilium reader in feminist liberation theology, 3-13. Maryknoll, NY: SCM.

Scott, B B [1989] 1990. Hear then the parable: A commentary on the parables of Jesus. Minneapolis: Fortress.

Sölle, D 1996. Paternalistic religion, in Schūssler Fiorenza, E (ed), The power of naming: A Concilium reader in feminist liberation theology, 150-158. Maryknoll, NY: SCM.

Soskice, J M 1985. Metaphor and religious language. Oxford: Clarendon.

Tillich, P 1957. Dynamics of faith. New York: Harper \& Row.

Van Wijk-Bos, J W H 1995. Reimaging God: The case for Scriptural diversity. Louisville, Kentucky: John Knox.

Von Wartenberg-Potter, B 1987. We will not hang our harps on the willows: Engagement and spirituality. Geneva: WWC Publications.

Washington, H C 1997. Violence and the construction of gender in the Hebrew Bible: A new historicist approach. Biblical Interpretation: A Journal of Contemporary Approaches 5/4, 324-363.

Wren, B 1989. What language shall I borrow? God-talk in worship: A male response to feminist theology. New York: Crossroad. 